\title{
Molecular identification of a new isolate of actinobacteria ATIS61 and characterization of the protease activities
}

\author{
FADHLIAH AMFAR ${ }^{1}$, LENNI FITRI $^{2, \boldsymbol{v}}$, SUHARTONO $^{2}$ \\ ${ }^{1}$ Program of Biology, Graduate Program, Faculty of Mathematics and Natural Sciences, Universitas Syiah Kuala. Jl. Syech Abdurrauf No. 3 , \\ Kopelma Darussalam, Syiah Kuala, Banda Aceh 23111, Aceh, Indonesia \\ ${ }^{2}$ Department of Biology, Faculty of Mathematics and Natural Sciences, Universitas Syiah Kuala. Jl. Syech Abdurrauf No. 3, Kopelma Darussalam, Syiah \\ Kuala, Banda Aceh 23111, Aceh, Indonesia. Tel.: +62-651-7410248, Fax.: +62-651-755138, `email: lennifitri@unsyiah.ac.id
}

Manuscript received: 30 January 2021. Revision accepted: 28 February 2021

\begin{abstract}
Amfar F, Fitri L, Suhartono. 2021. Molecular identification of a new isolate of actinobacteria ATIS61 and characterization of the protease activities. Biodiversitas 22: 1564-1569. Protease is an enzyme that catalyzes the hydrolysis of peptide bonds in protein. Actinobacteria are one of bacterial groups that is able to produce protease. Actinobacteria are Gram-positive bacteria and mostly aerobic. This study aimed to identify protease-producing actinobacteria ATIS61 isolate using 16S rRNA gene and to characterize the protease activity. This study was experimental research, consisted of amplification and sequencing of the 16S rRNA gene, and protease activity test. The 16S rRNA gene analysis showed that ATIS61 isolate was closely related to Nocardia sp. strain 335427 with a $99.88 \%$ similarity and the result of phylogenetic tree construction was related to Nocardia farcinica strain ARS8 with Bootstrap 94\%. Protease activity test showed the highest activity was on the eighth day of incubation at $0.115 \mathrm{U} / \mathrm{mL}$. Protease activity based on temperature showed the highest activity at $40^{\circ} \mathrm{C}$ of $0.156 \mathrm{U} / \mathrm{mL}$ and the stability of protease towards temperature was stable at $40^{\circ} \mathrm{C}$ and $50^{\circ} \mathrm{C}$. Protease activity showed that the highest protease activity was at $\mathrm{pH} 8$ of $0.096 \mathrm{U} / \mathrm{mL}$ and the highest protease stability was also at $\mathrm{pH}$ 8. The addition of $\mathrm{HgCl}_{2}$ showed that it could inhibit protease activity with a value of $0.059 \mathrm{U} / \mathrm{mL}$.
\end{abstract}

Keywords: Actinobacteria, ATIS61, enzyme activity, identification, protease

\section{INTRODUCTION}

The development of biotechnology has placed the use of enzymes as an alternative for various purposes, for example, in industry and medicine. One of the many enzymes studied was protease, which catalyzed the hydrolysis of peptide bonds in proteins. Protease could be produced by plants, animals and microorganisms. The proteases used in industry were generally produced by microorganisms. The protease market reached up to $60 \%$ of the total world sales of enzymes, where $40 \%$ of the protease came from microbial sources (Suhartono 2000). Microbes could be cultured in a relatively short time duration so that the enzyme could be produced in large quantities and easily. Actinobacteria are one of the microbial groups that are able to produce protease.

Actinobacteria are aerobic Gram-positive bacteria. Having a similar morphology to fungi, which have mycelium (Dilip et al. 2013). The form of actinobacteria colony is rounded with raised and convex elevations, flat and irregular edges, and powdery, rough, or wrinkled surfaces. The specialty of other forms of actinobacterial colony is that it is hydrophobic in nature, but its vegetative mycelium is hydrophilic (Miyadoh 2003). Actinobacteria are also called filamentous bacteria because the morphological characteristics of actinobacteria are more like filamentous fungi by forming spores and mycelium, but the cell structure and composition of the actinobacterial cell walls are similar to bacteria (Das et al. 2008).
Actinobacteria can be found in a wide variety of environments such as soil, desert, mountain craters, lake water, lake beds, hot springs, compost, peat, and other places with extreme temperatures. This is due to the ability of actinobacteria to produce spores (Limaye et al. 2017). Actinobacteria were good producers of biotechnology products, such as antibiotics, industrial enzymes, and other bioactive compounds. About 23,000 bioactive secondary metabolites produced by microorganisms have been reported, more than 10,000 compounds were produced by actinobacteria (Berdy 2005).

Based on research conducted by Fitri et al. (2019), a total of 6 actinobacteria obtained namely ATIS51, ATIS61, ATIS62, ATIS63, ATIS64, and ATIS65, were isolated from hot springs located in Ie Seu'um Village, Masjid Raya Subdistrict, Aceh Besar District and only 4 isolates namely ATIS61, ATIS62, ATIS63 and ATIS64 which had the ability to produce protease. The Proteolytic Index (PI) values obtained from ATIS61, ATIS63, and ATIS64 were $3.8,2$, and $1.6 \mathrm{~cm}$ respectively, while the PI values of ATIS62 could not be calculated because the diameter of the clear zone formed was too small. This prompted a study of the isolates that produce the highest protease enzyme compared to other isolates, namely the actinobacterial isolate ATIS61, to determine the types of species and the enzyme activity they produce.

Therefore, this study was aimed to conduct molecular identification using the 16S rRNA gene towards proteaseproducing actinobacteria ATIS61 isolated from hot springs. 
This study also aimed to characterize protease activity produced by actinobacteria.

\section{MATERIALS AND METHODS}

\section{Culturing actinobacteria}

The actinobacteria used in this study was ATIS61 isolate, which was obtained from Ie Seu'um hot springs, Aceh Besar, Indonesia (Fitri et al. 2019). The actinobacteria were recultured by inoculating bacterial isolate in a plate containing yeast malt extract (YM) agar. The plate that has been streaked then incubated at $44^{\circ} \mathrm{C}$ for approximately one week and the isolated growth was observed.

\section{Molecular identification}

Identification of selected isolates was conducted based on $16 \mathrm{~S}$ rRNA gene sequences. DNA extraction was carried out using Genomic DNA Mini Kit (Geneaid) followed by amplification of the 16S rRNA gene using primer Bact 27F (5'-AGAGTTTGATCATGGCTCAG-3') and UniB 1492R (5'-GGTTACCTTGTTACGACTT-3'). The 16S rRNA gene sequences were determined by sequencing the nucleotides using the services of PT. Genetics Science (Jakarta, Indonesia) that collaborates with $1^{\text {st }}$ Base (Malaysia). The 16S rRNA gene sequences from the two primers were edited, aligned and combined using Bioedit software. The consensus of the merged sequences was saved in the FASTA format. Then the base sequences of each isolate were compared with other microorganisms in the Gen Bank using Nucleotide Basic Alignment Search Tools (BLAST-N). BLAST-N can be accessed on the National Center for Biotechnology Information (NCBI) website. In addition, sequence analysis was also carried out using DNA Subway open-access software. Furthermore, the construction of phylogenetic trees was carried out using Molecular Evolutionary Genetics Analysis (MEGA) Version X program (Tamura et al. 2013).

\section{Protease activity test}

Actinobacterial isolate was transferred into an Erlenmeyer flask containing yeast malt broth + skim milk (YMBS) media using a cork borer. The inoculum then incubated in an incubator shaker with an agitation speed of $150 \mathrm{rpm}$ at room temperature. After the sixth day, the protease enzyme crude extract was harvested every 24 hours until the 11th day to determine the optimum enzyme production time. The protease enzyme crude extract was harvested by taking the supernatant from inoculum centrifugation at a speed of $8,000 \mathrm{~g}$ for 5 minutes.

Protease activity was measured by using modified Walter (1984) method (Table 1). A total of $100 \mu \mathrm{L}$ of protease crude extract was added with $0.5 \mathrm{~mL}$ of $1 \%$ casein $(w / v)$ and incubated for 10 minutes at $37^{\circ} \mathrm{C}$. The reaction between the protease crude extract and casein was stopped by adding $10 \%$ trichloroacetic acid (TCA) and incubated for 10 minutes at $10^{\circ} \mathrm{C}$. The reaction solution was centrifuged at a speed of $8,000 \mathrm{~g}$ for 10 minutes and then the supernatant was collected. Afterward, $0.5 \mathrm{M} \mathrm{Na}_{2} \mathrm{CO} 3$ and Folin Ciocalteau reagent (1:2) were added, then homogenized and incubated for 10 minutes at room temperature. After incubation, the absorbance of the solution was measured by using spectrophotometer at a wavelength of $578 \mathrm{~nm}$. One unit of enzyme activity was defined as the amount of enzyme that released $1 \mu \mathrm{mol}$ of tyrosine per minute at optimum temperature and $\mathrm{pH}$ (Suhartono and Artika 2017).

Blank test, as much as $0.5 \mathrm{~mL}$ of $1 \%(\mathrm{w} / \mathrm{v})$ casein was added with $0.1 \mathrm{~mL}$ of distilled water and incubated for 10 minutes at $10{ }^{\circ} \mathrm{C}$. Added $1 \mathrm{~mL}$ trichloroacetic acid (TCA) and $0.1 \mathrm{~mL}$ enzyme and incubated for 10 minutes at $10^{\circ} \mathrm{C}$. The reaction solution was centrifuged at a speed of 10000 rpm for 5 minutes and the supernatant was collected. Then the solution was added with $2.5 \mathrm{~mL}$ of $0.5 \mathrm{M} \mathrm{Na}_{2} \mathrm{CO} 3$ and $0.5 \mathrm{~mL}$ of Folin Ciocalteau (1: 2) reagent before being homogenized and incubated for 15 minutes at room temperature. After incubation, the absorbance of the solution was measured by using spectrophotometer at a wavelength of $578 \mathrm{~nm}$. One unit of enzyme activity was defined as the amount of enzyme that releases $1 \mu \mathrm{mol}$ of tyrosine per minute at optimum temperature and $\mathrm{pH}$ (Walter 1984).

Standard test, as much as $0.5 \mathrm{~mL}$ of $1 \%$ (w/v) casein was added with $0.1 \mathrm{~mL}$ of standard tyrosine $5 \mathrm{mM}$ and incubated for 10 minutes at $10^{\circ} \mathrm{C}$. Added $1 \mathrm{~mL}$ trichloroacetic acid (TCA) and $0.1 \mathrm{~mL}$ enzyme and incubated for 10 minutes at $10^{\circ} \mathrm{C}$. The reaction solution was centrifuged at a speed of $10000 \mathrm{rpm}$ for 5 minutes and the supernatant was collected. Then the solution was added with $2.5 \mathrm{~mL}$ of $0.5 \mathrm{M} \mathrm{Na}_{2} \mathrm{CO} 3$ and $0.5 \mathrm{~mL}$ of Folin Ciocalteau (1: 2) reagent before being homogenized and incubated for 15 minutes at room temperature. After incubation, the absorbance of the solution was measured by using spectrophotometer at a wavelength of $578 \mathrm{~nm}$. One unit of enzyme activity was defined as the amount of enzyme that releases $1 \mu \mathrm{mol}$ of tyrosine per minute at optimum temperature and $\mathrm{pH}$ (Walter 1984).

\section{Effect of temperature on the activity and stability of Protease}

The optimal temperature required for enzymatic reactions was determined by measuring protease activity at various temperatures $\left(30^{\circ} \mathrm{C}, 40^{\circ} \mathrm{C}, 50^{\circ} \mathrm{C}, 60^{\circ} \mathrm{C}\right.$, and $\left.70^{\circ} \mathrm{C}\right)$. The steps conducted were same as in the enzyme activity test. The stability of protease against temperature was measured by incubating the enzyme solution for $20,40,60$ and 80 minutes at various temperatures $\left(30^{\circ} \mathrm{C}, 40^{\circ} \mathrm{C}, 50^{\circ} \mathrm{C}\right.$, $60^{\circ} \mathrm{C}$, and $70^{\circ} \mathrm{C}$ ), immediately after incubation. The enzyme solution was cooled rapidly and the remaining protease activity was measured in the same method (Fatimah and Wardani 2014).

\section{Effect of $\mathrm{pH}$ on the activity and stability of Protease}

The optimal $\mathrm{pH}$ required for enzymatic reactions was determined by measuring protease activity at various $\mathrm{pH}$ levels $(5,6,7,8$, and 9) using the optimum temperature obtained in the previous step. The steps conducted were same as in enzyme activity test. The stability of protease against $\mathrm{pH}$ was measured by incubating the enzyme solution for 1 hour at $4^{\circ} \mathrm{C}$ at various $\mathrm{pHs}(5,6,7,8$, and 9). 
Immediately after incubation, the activity of the remaining protease was measured in the same method (Fathimah and Wardani 2014).

\section{Effect of inhibitors on Protease activity}

The effect of adding inhibitor was determined by testing protease activity at optimum temperature and optimum $\mathrm{pH}$ obtained in the previous steps. $10 \mathrm{mM} \mathrm{HgCl}_{2}$ and $0,1 \mathrm{~mL}$ protease enzyme were added, then incubated for one hour at room temperature (Fathimah and Wardani 2014).

\section{RESULTS AND DISCUSSION}

\section{Molecular identification of actinobacteria}

Based on the research that has been conducted, ATIS61 colony had a rough and velvety structure. The bacterial isolate had white aerial mycelium color on the edges and cream-colored in the middle, light brown substrate mycelium color, a diffuse pigment that was ivory, and a button elevation (Fitri et al. 2019). Microscopic characterization was carried out to see the hyphae form of actinobacterial isolate. The results obtained were that ATIS61 had a straight hyphae form (rectis) (Figure 1).

Molecular identification was carried out on actinobacteria that able to produce the highest protease, it was ATIS61. The Proteolytic Index (PI) value obtained from the ATIS61 isolate was $3.8 \mathrm{~cm}$ (Fitri et al. 2019). The first step was to extract genomic DNA from ATIS61 using DNA Genome Purification Kit-Promega Wizard. The extraction results were then checked for the purity and DNA concentration using Nanodrop. The results obtained showed that the level of purity of ATIS61 was $2.09 \mathrm{~nm}$ with a concentration of $29.8 \mathrm{ng} / \mu 1$.

The results of DNA extraction then used as a template for amplification using PCR using Bact 27F-Uni 1492R primers. Based on the amplification results, it could be seen that the DNA fragment of the ATIS61 had a size of about $1500 \mathrm{bp}$. This showed that the amplified area was $16 \mathrm{~S}$ rRNA gene which was the target of amplification. The 27F primer was designed to amplify $16 \mathrm{~S}$ rRNA coding gene in Gram-positive bacteria including the genus Streptomyces, while the $1492 \mathrm{R}$ primer was designed for the entire bacterial domain (Weisburg et al. 1991).

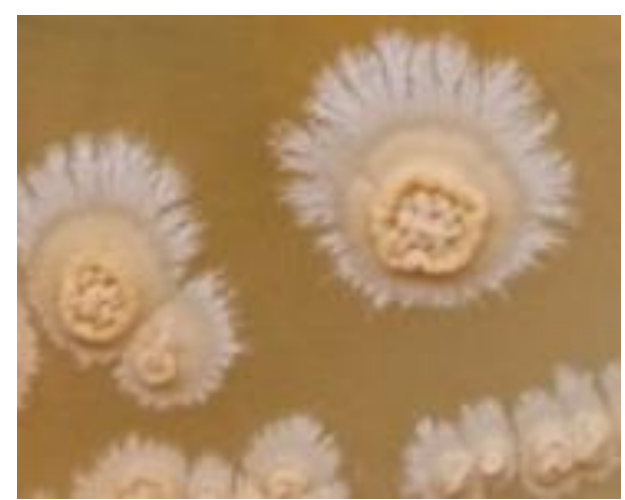

A
After obtaining amplification results, the method continued with 16S rRNA gene sequencing which was carried out by a sequencing service provider, PT. Genetics Science. The results of BLAST analysis were to find the similarity between the research results and the sequences contained in the GenBank DNA Database.

Based on the results obtained, ATIS61 sequence was 99.88\% similar to Nocardia farcinica. According to Drancourt et al. (2000), the value of 16S rRNA sequence homology greater than $99 \%$ could represent the same species, meanwhile, sequence homology less than $97 \%$ only represented the same genus. According to Jauh-Hsun et al. (2002) and Patel et al. (2004), homology value of $98 \%$ or less indicates a different species or could be considered as a new species. However, in some cases, actinobacteria could be classified into new species even though the $16 \mathrm{~S}$ rRNA homology was above $98 \%$.

Based on BLAST results, it was necessary to analyze phylogeny to describe the position and kinship between the research sequences and the sequences available in NCBI GenBank DNA Database.

Based on Figure 2, the results of phylogenetic tree analyses revealed that ATIS61 was related to Nocardia farcinica strain ARS8 with Bootstrap value of $94 \%$. The construction of phylogenetic tree in this study used neighbor-joining algorithm method with 1000 times replication. The values shown in the phylogenetic tree branch were bootstrap values. The bootstrap value showed the accuracy level of the branching on phylogenetic tree. The greater the bootstrap value, the higher the level of topological confidence in the reconstruction of phylogenetic trees (Yuliani et al. 2017).

Nocardia has a velvety texture when it was sporulated. The color of substrate mycelium was red, while the texture of the colony that had not sporulated was wrinkled in the middle, unicellular, and the reversion was colorless (Pujiati 2014). Nocardia is a motile and non-motile, aerobic bacteria which produced enzyme. It could be found in soil, water, plant and animal tissue (Abdelmohsen et al. 2014). It the second-largest genus found with an abundance of $6.6 \%$ which was abundant in obligate aerobic soils and some was pathogenic in animals and humans. This genus was also active in degrading cellulose and dissolving phosphate (Nofu 2014).

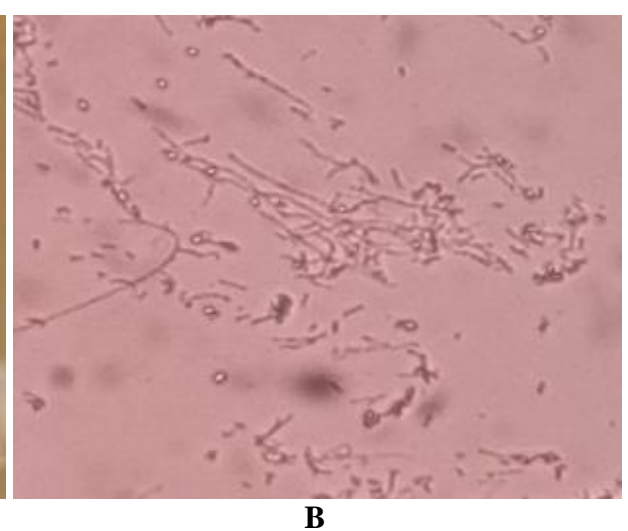

Figure 1. Morphological characterization of (A) colonies of ATIS61, and (B) microscopic of ATIS61 cells at 1000x magnification (Fitri et al. 2019). 


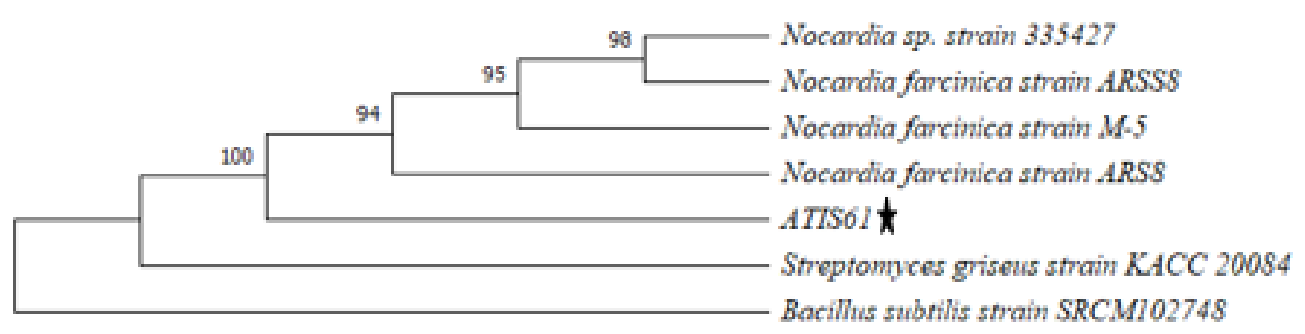

Figure 2. ATIS61 phylogenetic tree construction based on 16S rRNA gene

\section{Characterization of protease \\ Protease activity}

Protease production was carried out in YMBS medium and incubated in an incubator shaker at a speed of $150 \mathrm{rpm}$ at room temperature for 11 days. Observations were made from the $6^{\text {th }}$ day of incubation to the $11^{\text {th }}$ day to determine the optimum time of enzyme production. Furthermore, protease activity test was carried out referring to the modified Walter (1984) method (Suhartono and Artika 2017).

The lowest protease activity of ATIS61 was observed on the $6^{\text {th }}$ day, which was $0.039 \mathrm{U} / \mathrm{mL}$. The highest protease activity was at the $8^{\text {th }}$ day, with a value of 0.115 $\mathrm{U} / \mathrm{mL}$. Meanwhile, on the $9^{\text {th }}$ day onwards, the protease activity had decreased. It was suspected that ATIS61 on the 6th day just started producing protease (Figure 3). Research conducted by Suhartono and Artika (2017) also reported that the protease activity of AKJ-09 was the highest when the isolate was 8 days old, which was $0.088 \mathrm{U} / \mathrm{mL}$.

The increase in enzyme activity at the beginning of the production period was thought to be caused by the availability of large amounts of nutrients needed by bacterial cells to carry out cell metabolisms. At the end of the enzyme production time, there was a decrease in proteolytic activity which could occur due to the reduced number of substrates that would inhibit the formation of the substrate enzyme complex and change enzyme structure which could cause a decrease in the catalytic rate (Yuniati et al. 2015).

\section{Effect of temperature on the activity and stability of protease}

Generally, enzyme had a maximum activity at a certain temperature, enzyme activity would increase with the increasing temperature until the optimum temperature was reached, further temperature increase would cause enzyme activity to decrease.

It could be seen in Figure 4 that the highest protease activity of ATIS61 was at a temperature of $40^{\circ} \mathrm{C}$ with an average proteolytic activity of $0.156 \mathrm{U} / \mathrm{mL}$ and began to decline at a temperature of $50{ }^{\circ} \mathrm{C}$ onwards. The lowest protease activity of ATIS61 was at $70^{\circ} \mathrm{C}$ with a value of $0.057 \mathrm{U} / \mathrm{mL}$. Research conducted by Yuratmoko (2005) found that SLW 8-1 isolate had three activity peaks, those were at temperatures of 40,50 , and $80^{\circ} \mathrm{C}, \mathrm{C} 1-3$ isolate at $40^{\circ} \mathrm{C}$ and $451-3$ isolate had optimum temperature at $50^{\circ} \mathrm{C}$.

Temperature affects the rate of enzyme catalysis reaction in two ways. Firstly, increasing the temperature which also increases the energy of the substrate molecules and ultimately increases the rate of enzyme reactions. Second, the increases in thermal energy of the molecules that make up the protein structure of the enzyme itself will cause the breakdown of non-covalent interaction (hydrogen bond, van der wall bond, hydrophobic bond, and electrostatic interaction) that keep the enzyme 3D structure together so that the enzyme denatures (Hames and Hooper 2000).

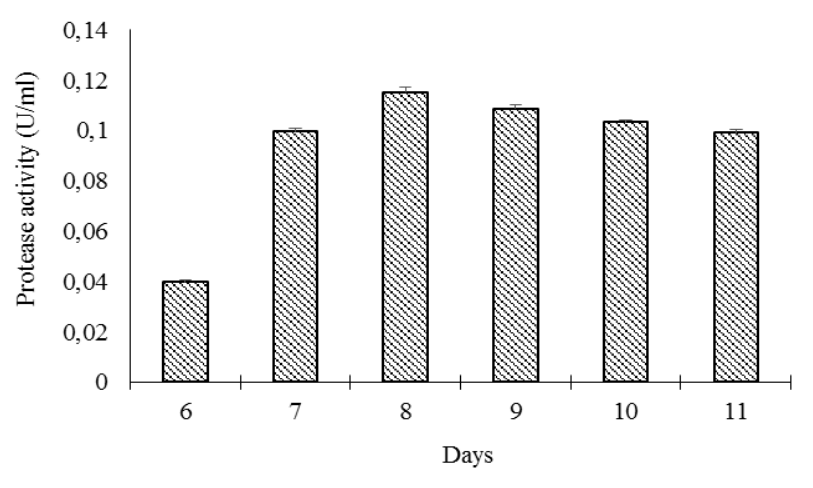

Figure 3. Protease activity after growing in YMBS medium at $28^{\circ} \mathrm{C}$

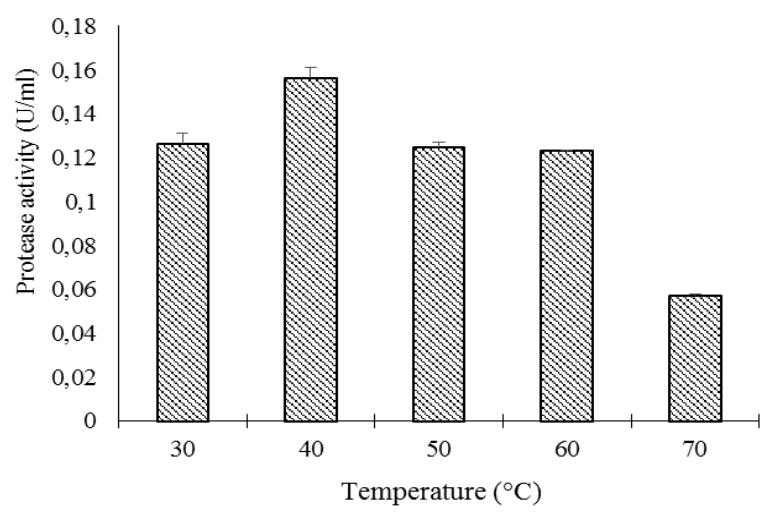

Figure 4. The effect of temperature on protease activity of ATIS61 


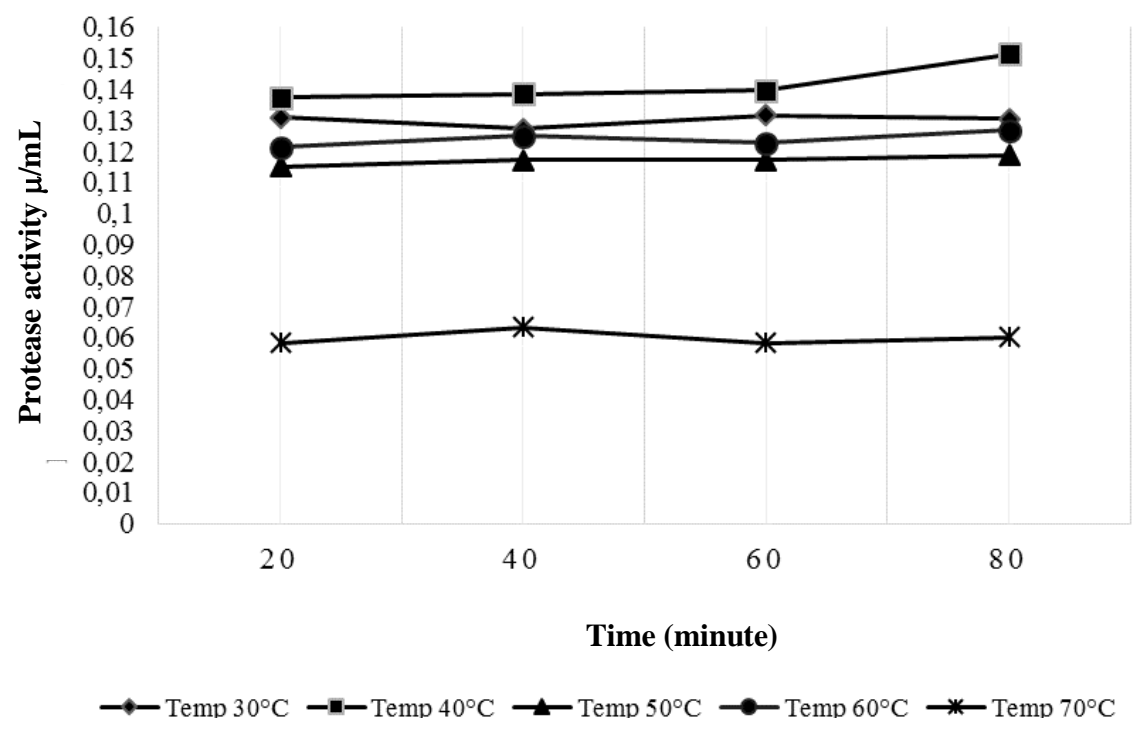

Figure 5. Temperature stability on protease activity of ATIS61 when incubated in different time duration (minutes)

The protease stability against temperature showed that protease activity of ATIS61 at 30,60 and $70^{\circ} \mathrm{C}$ was relatively fluctuating, while at 40 and $50^{\circ} \mathrm{C}$ was relatively stable (Figure 5). According to Sianturi (2008), currently, what was required in an enzyme-based industry was the stability of the enzyme so that it did not decrease. Then it was necessary to test the protease stability against temperature.

\section{Effect of $\mathrm{pH}$ on the activity and stability of protease}

All enzymatic reactions were influenced by $\mathrm{pH}$, so a buffer was needed to control $\mathrm{pH}$ of the reaction. The extract of ATIS61 enzyme showed the highest activity at $\mathrm{pH} 8$, namely $0.096 \mathrm{U} / \mathrm{mL}$ and the lowest protease activity at $\mathrm{pH} 5$, namely $0.045 \mathrm{U} / \mathrm{mL}$ (Figure 6). Research conducted by Soeka and Sulistiani (2017) on Stenotrophomonas sp. from Mount Bromo showed that the optimum protease activity was at $\mathrm{pH} 8$ which was 419.68 $\mathrm{U} / \mathrm{mL}$ (Figure 7). Murray (2003) also stated that changes in $\mathrm{pH}$ affect enzyme activity by changing the structure or the residue that functions to bind the substrate or catalyst, as a result, substrate hydrolysis was not complete.

Based on the results, the lowest protease activity was at $\mathrm{pH} 5$ with a value of $0.043 \mathrm{U} / \mathrm{mL}$, and the highest protease activity was at $\mathrm{pH} 8$ with a value of $0.049 \mathrm{U} / \mathrm{mL}$, then decreased at $\mathrm{pH} 9$ with a value of $0.046 \mathrm{U} / \mathrm{mL}$ (Figur 8). This indicated that protease activity of ATIS61 could work optimally in neutral and alkaline conditions.

\section{Effect of inhibitors on protease activity}

The characterization of the effect of inhibitor on protease activity of ATIS61 was observed using $\mathrm{HgCl}_{2}$ inhibitor. The protease activity without the addition with $\mathrm{HgCl}_{2}$ was $0.096 \mathrm{U} / \mathrm{mL}$ and was $0.059 \mathrm{U} / \mathrm{mL}$ with the addition $\mathrm{HgCl}_{2}$ inhibitor (Figure 8). This showed that $\mathrm{HgCl}_{2}$ could inhibit protease activity obtained from ATIS61 and most likely the enzyme produced by ATIS61 belonged to the cysteine group. Research conducted by Yang et al. (2000) against Bacillus sp. also get the same result, that was $\mathrm{Hg}^{2+}$ ion caused protease inhibition.

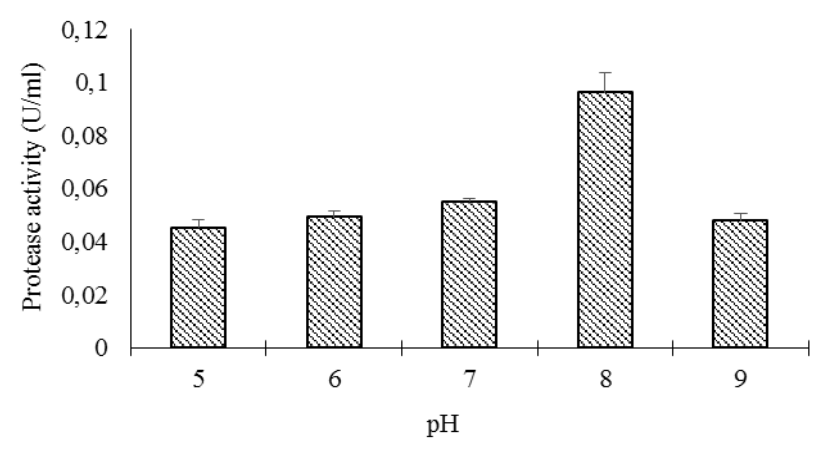

Figure 6. The curve of the influence of $\mathrm{pH}$ on protease activity of ATIS61

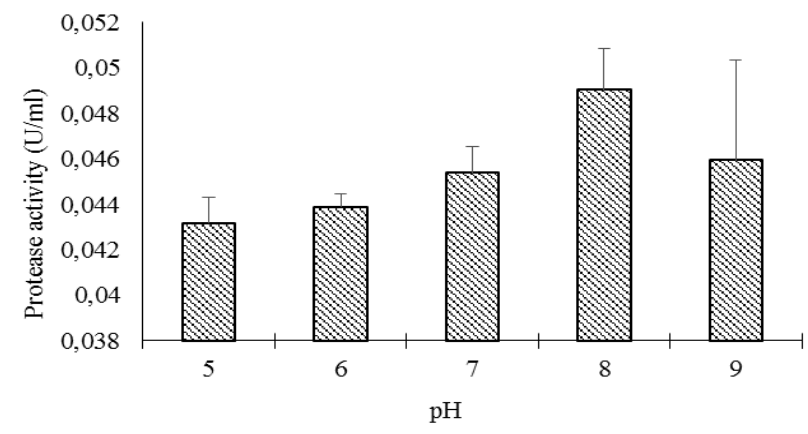

Figure 7. pH stability curve on protease activity of ATIS61 


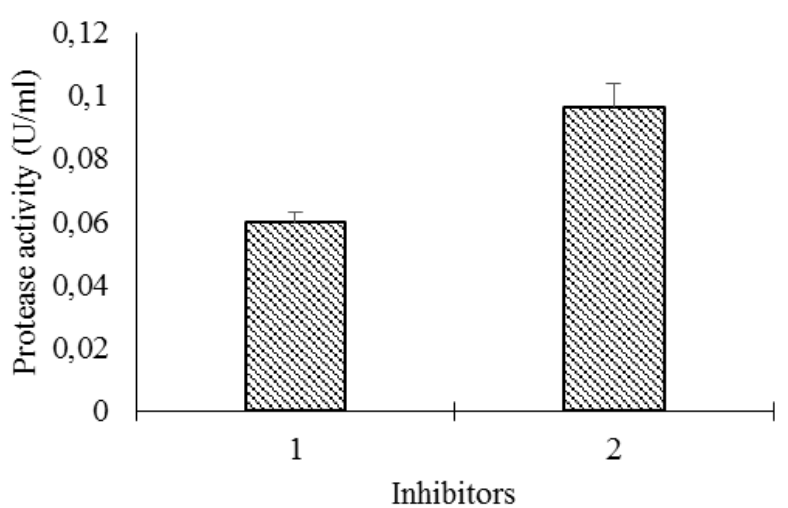

Figure 8. Inhibitor curve on protease activity of ATIS61 (1. $\mathrm{HgCl}_{2}$ and 2. Non- $\mathrm{HgCl}_{2}$ )

Metal ions were needed in the form of monovalent and divalent cations as activators that could increase the activity of certain enzymes. However, these ions could also act as inhibitors, that is substances that could reduce or inhibit enzyme activity at certain concentrations (Chen et al. 2009).

In conclusion, based on this study, ATIS61 sequence was $99.88 \%$ similar to Nocardia farcinica sequence stored in the GenBank DNA NCBI database. The results of phylogenetic tree construction showed that ATIS61 was related to Nocardia farcinica strain ARS8 with Bootstrap value of $94 \%$. The highest protease activity was on the $8^{\text {th }}$ day, with a value of $0.115 \mathrm{U} / \mathrm{mL}$. And the highest protease activity of ATIS61 was at a temperature of $40^{\circ} \mathrm{C}$ with an average proteolytic activity of $0.156 \mathrm{U} / \mathrm{mL}$. The protease stability against temperature showed that protease activity of ATIS61 at 30, 60 and $70^{\circ} \mathrm{C}$ was relatively fluctuating, while at 40 and $50^{\circ} \mathrm{C}$ was relatively stable. The crude extract of ATIS61 enzyme showed the highest activity at $\mathrm{pH} 8$, which was $0.096 \mathrm{U} / \mathrm{mL}$. The protease stability against $\mathrm{pH}$ showed the highest protease activity was at $\mathrm{pH}$ 8 with a value of $0.049 \mathrm{U} / \mathrm{mL}$. The protease activity without the addition with $\mathrm{HgCl}_{2}$ was $0.096 \mathrm{U} / \mathrm{mL}$ and protease activity with the addition $\mathrm{HgCl}_{2}$ inhibitor was $0.059 \mathrm{U} / \mathrm{mL}$. This showed that $\mathrm{HgCl}_{2}$ could inhibit protease activity obtained from ATIS61.

\section{REFERENCES}

Abdelmohsen UR, Yang C, Horn H, Hajjar D, Ravasi T, Hentschel U. 2014. Actinomycetes from Red Sea sponges: sources for chemical and phylogenetic diversity. Mar Drugs 12 (5): 2771-2789. DOI: $10.3390 / \mathrm{md} 12052771$.

Berdy J. 2005. Bioactive microbial metabolites. J Antibiot 58: 1-26. DOI 10.1038/ja.2005.1.

Chen HQ, Chen XM, Li Y, Wang J, Jin ZY, Xu XM, Zhao JW, Chen TX, Xie ZJ. 2009. Purification and characterisation of exo- and endoinulinase from Aspergillus ficuum. JNSP5-06. Food Chem 115: 12061212. DOI: 10.1016/j.foodchem.2009.01.067.

Das S, Lyla PS, Khan SA. 2008. Distribution and generic composition of culturable marine actinomycetes from the sediments of Indian continental slope of Bay of Bengal. Chin J Oceanol Limnol 26: 166177. DOI: 10.1007/s00343-008-0166-5.
Dilip CV, Mulaje S, Mohalkar R. 2013. On actinomycetes and their biotechnological application - A Review. Int J Pharm Sci Res 4: 1730-1742.

Drancourt M, Bollet C, Carlioz A, Martelin RC. 2000. 16S Ribosomal DNA sequence analysis of a large collection of environmental and clinical unidentifiable bacterial isolates. J Clin Microbiol 38: 36233630. DOI: 10.1128/JCM.38.10.3623-3630.2000.

Fatimah AN, Wardani AK. 2014. Extraction and characterization of protease from the leaves of Moringa oleifera Lamk. Jurnal Teknologi Pertanian 153: 191-200. [Indonesia]

Fitri L, Putri KA, Suhartono, Ismail YS. 2019. Isolation and characterization of thermophilic actinobacteria as proteolytic enzyme producer from Ie Seuum Hot Spring, Aceh Besar, Indonesia. Biodiversitas 20: 2802-2808. DOI: 10.13057/biodiv/d201004.

Hames BD, Hooper NM. 2000. Biochemistry: The Instant Notes 2nd ed. Springer-Verlag, Hongkong.

Jauh-Hsun C, Vinh T, Davies JK, Figdor D. 2002. Molecular approaches to the differentiation of Actinomycetes species. J Mol Oral Microbiol 14: 250-256. DOI: 10.1034/j.1399-302X.1999.140409.x.

Limaye L, Patil R, Ranadive P, Kamath G. 2017. Application of Potent Actinomycetes strain for Bio-Degradation of Domestic Agro- Waste by composting and treatment of Pulp-Paper mill effluent. Adv Microbiol 7: 94-108. DOI: 10.4236/aim.2017.71008.

Miyadoh S. 2003. Actinomycetes characterization and identification procedure. Laporan Training Course on Identification of Bacteria. Bogor, 1-5 April 2003. [Indonesian]

Murray RK. 2003. Harper's Biochemistry. Hartono A, translater. Bani AP, Sikumbang TMN, editor. EGC Penerbit Buku Kedokteran, Jakarta. [Indonesian]

Nofu K, Khotimah S, Lovadi I. 2014. Isolation and characterization of cellulose-degrading bacteria on yellow bagasse. Protobiont 3: 25-33. DOI: http://dx.doi.org/10.26418/protobiont.v3i1.4577. [Indonesian]

Patel JB, Wallace RJ, BA, Jr., Coklat-Elliott, Taylor T, Imperatrice C, Leonard DBG, Wilson RW, Mann L, Jost KC, Nachamkin I. 2004. Sequence-based identification of aerobic Actinomycetes. J Clin Microbiol 42 (6): 2530-2540. DOI: 10.1128/JCM.42.6.25302540.2004 .

Pujiati. 2014. Isolation of actinomycetes from garden soil as a guide for microbiology practice. Jurnal Florea 1: 42-46. [Indonesian]

Sianturi DC. 2008. Isolation of bacteria and coarse thermophile amylase test from hot springs harvested in Sibirubiru, North Sumatra. [Thesis]. Universitas Sumatera Utara, Medan. [Indonesian]

Soeka YS, Sulistiani. 2017. Characterization of protease from Stenotrophomonas sp. from Mount Bromo, East Java. Berita Biologi 16: 203-211. DOI: 10.14203/beritabiologi.v16i2.2940. [Indonesian]

Suhartono MT. 2000. Exploration of bacterial protease from Indonesia for industrial applications and biotechnology research. Prosiding Seminar Nasional Industri Enzim dan Bioteknologi II 125-133. [Indonesian]

Suhartono S, Artika W. 2017. Isolation and protease activity assay of local actinobacteria isolates (AKJ-09) Aceh. Bioleuser 1: 116-120. [Indonesian]

Tamura K, Stecher G, Peterson D, Filipski A, Kumar S. 2013. MEGA 6: Molecular evolutionary genetic analysis version 6.0. Mol Biol Evol 30: 2725-2729.

Walter HE. 1984. Proteases and their inhibitors. 2. 15. 2 Method with haemoglobin, casein, and azocoll as substrate. Methods Enzym Anal 270-277.

Weisburg WG, Barns SM, Pelletier DA, Lane DJ. 1991. 16S ribosomal DNA amplification for phylogenetic study. J Bacteriol 173: 697-703.

Yang JK, Shih IL, Tzeng YM, Wang SL. 2000. Production and purification of protease from a Bacillus subtilis that can deproteinize crustacean wastes. Enzyme Microb Technol 26: 406-413. DOI: 10.1016/S0141-0229(99)00164-7.

Yuliani Y, Yuniaty A, Susanto AH. 2017. Variation of DNA sequences that were amplified using atpB-rbcl primer on several peanut cultivars. Scripta Biol 4: 11. [Indonesian]

Yuniati R, Nugroho TT, Puspita F. 2015. Protease activity test of Bacillus sp. Riau local line. JOM FMIPA 1: 116-122. [Indonesian]

Yuratmoko D. 2005. Screening and Characterization of Streptomyces spp. proteolytic from Indonesia. [Thesis]. Fakultas Matematika dan Ilmu Pengetahuan Alam, Institut Pertanian Bogor, Bogor. [Indonesian] 